\title{
Effect of Oral Administration of Aqueous Leaves Extracts of Euphobia Lateriflora (Schum and Thonn) On Liver and Kidney Function in Rats
}

\author{
${ }^{1}$ Usman M.M and ${ }^{2}$ Sule M. S \\ ${ }^{I}$ Department of Biotechnology, ModibboAdama University of Technology, P.M.B 2076 Yola, Adamawa State. \\ Nigeria. \\ ${ }^{2}$ Department of Biochemistry, Bayero University, Kano, P.M.B 3011, Kano, Kano State. Nigeria.
}

\begin{abstract}
The effect of administration of graduated dose of aqueous leaf extract of Euphobia lateriflora on $A L T$, AST, ALP, bilirubin, total protein, creatinine and urea was determined to acertain the toxic effect of the extract on the liver and kidney. Significantly lower levels of AST and urea $(\mathrm{p}<0.05)$ were observed in group administered with $100 \mathrm{mg} / \mathrm{kg}$ leaf extract. There was no significant difference $(p>0.05)$ in ALT, ALP and levels of total protein in group administered with $100 \mathrm{mg} / \mathrm{kg}$ aqueous extract and also ALT, AST, ALP and levels of bilirubin, total protein, creatinine and urea in groups administered with $250 \mathrm{mg} / \mathrm{kg}$ leaf extract compared to the control. The result suggest no possible hepatotoxic effect and kidney malfunction after administration of $100 \mathrm{mg} / \mathrm{kg}$ and $250 \mathrm{mg} / \mathrm{kg}$ leaf extract. The result of the oral acute toxicity study shown that Euphobia lateriflora have oral $L D_{50}$ above $5000 \mathrm{mg} / \mathrm{kg}$.

ALT: Alanine aminotransferese, AST: Aspatateaminotransferese and ALP: Alkaline Phosphatese
\end{abstract}

\section{Introduction}

Medicinal plants are believed to be an important source of new chemical substances with potential therapeutic effects (Farnsworth, 1989 and Eisner, 1990). Many indigenous plants have been in the use of man since time immemorial for curing various ailments without the actual knowledge of their toxic potential (Egwin, Badru and Ajiboye, 2002). The ethnobotanical uses of plants are diverse in traditional practice (Agunu, Ibrahim, Onyiloyi and Abdulrahman, 2003), and the use of plants for medicinal purposes dates back to antiquity (Ogunyemi, 1979).

Medicinal plants are now widely being used in many parts of the world for the remedy of many disease (Sule, Bichi and Atiku, 2002). One of the problems of using plants as medicines is that in many cases no definite doses are prescribed, often resulting in overdose.

Liver is the largest organ in the body of vertebrates. The liver is particularly susceptible to chemical injury because of its anatomical relationship to the most important portal of entry, the gastrointestinal tract; and the high concentration of xenobiotic - metabolizing enzymes (Hodgson, Mailman and Chambers, 1988).

The Kidney performs the functions of getting rid of the body's waste materials that are either ingested, produced by metabolism or as a result of detoxification of the liver. This, and other functions of the kidney, can be disrupted by accumulation of toxic metabolites or chemicals leading to renal diseases (Arthur and John, 2000).

Euphorbia lateriflora (Fiddasartse in Hausa) is a shrub with smooth - gracious and erect branches. The leaves of this plant serve for the treatment of dermatoses (Hambali, 1990), intestinal parasitosis and convulsive fever in children (Adjanohounet al., 1991). E. Lateriflora extract was shown to exhibit antiviral activity using the measles virus on human epidermoid carcinoma cell line (Obi, Iroagba and Ojioko, 2006).

In spite of its widespread use as medicine in some parts of Nigeria and other parts of West Africa, data on the toxicological analysis of E. lateriflora is scarce or non - existent.

\section{EXPERIMENTAL ANIMALS}

\section{Materials And Methods}

Seventy six (76) albino rats of both sexes were obtained from National Veterinary Research Institute Vom, Jos. The animals were kept in cages in the animal house of the Department of Biological Sciences, Gombe State University and the animals had free access to normal diet (Growers marsh, vital feeds Ltd) and water.

\section{EXTRACTS PREPARATION}

The leaves of Euphobia lateriflora was collected from around Galinja village in Madobi Local Government Area, Kano State. They were authenticated at the Botany unit of Biological Sciences Department, Bayero University Kano. The leaves were dried and ground to powder using pestle and mortar. For 
subacutetoxicity studies $40 \mathrm{~g}$ of leaves was dissolved in $500 \mathrm{~cm}^{3}$ of distilled water and filtered after 24 hours. The residues were dried. The difference between the original weight and final weight was found to be the concentration of the extract. The filtrate was concentrated to $300 \mathrm{~cm}^{3}$ using oven drier. The concentration for leaves was found to be $8.4 \mathrm{~g} / 300 \mathrm{~cm}^{3}$. For acute toxicity studies, the plant leaves was dissolved in water and filtered after 24 hours. The filtrate was evaporated to dryness in an oven. The dried extract was weighed and dissolved in distilled water to a concentration of $11.3 \mathrm{~g} / 60 \mathrm{~cm}^{3}$.

\section{EXPERIMENTAL DESIGN}

Subacute Toxicity

Twenty eight (12) rats (body weight ranging from 100 to $162 \mathrm{~g}$ ) were used. The animals were divided into three groups of 4 rats each. Groups I and II were the study groups, while group III served as control group.

Rats in groups I and II were administered orally with $100 \mathrm{mg} / \mathrm{kg}$ and $250 \mathrm{mg} / \mathrm{kg}$ of aqueous leaf extract of Euphorbia lateriflora respectively. The animals in group III (control) were administered with distilled water. The administration of aqueous extracts was done once every twenty four (24) hours for the period of three weeks .

\section{Acute Toxicity}

Sixteen (16) rats (body weight ranging from 67.3 to $209 \mathrm{~g}$ ) were used for acute toxicity studies. Four groups of rats (4 per group) were administered orally with different doses $(2000,3000,4000$ and $5000 \mathrm{mg} / \mathrm{kg}$ ) of the extracts. The number of deaths in each group within 24 hours was recorded.

\section{COLLECTION AND PREPARATION OF BLOOD SAMPLES}

At the end of third week of oral administration of aqueous extracts, the rats were sacrificed by decapitation. Blood samples were collected into centrifuge tubes. The blood was allowed to clot at room temperature for 5 minutes, after which an applicator stick was used to carefully loosen the blood. The blood was then centrifuged at 2500rpm for 10 minutes. A clean Pasteur pipette was used to carefully collect the serum and dispensed into a clean labeled specimen bottle.

Sera samples collected were analyzed for activities of alanine aminotransferase (Reitman and Frankel, 1957), aspartate aminotransferase (Reitman and Frankel, 1957), alkaline phosphatase (Rec, 1972) and levels of bilirubin (Jedrassik and Grof, 1938)., total protein (Weichselbaum, 1946), creatinine (Bartels and Bohmer, 1971) and urea (Weatherburn, 1967).

\section{Results}

Table 1: Effects of the aqueous leaf extract of Euphorbia lateriflora on serum ALT, AST, ALP, bilirubin, total protein, creatinine and urea.

\begin{tabular}{|c|c|c|c|c|c|c|c|}
\hline Group & $\begin{array}{c}\text { ALT } \\
\left(\mathbf{U} / \mathrm{dm}^{3}\right)\end{array}$ & $\begin{array}{c}\text { AST } \\
\left(\mathbf{U} / \mathrm{dm}^{3}\right) \mathbf{s}\end{array}$ & $\begin{array}{c}\text { ALP } \\
\left(\mathbf{U} / \mathrm{dm}^{3}\right)\end{array}$ & $\begin{array}{c}\text { Bilirubin } \\
\left(\mu \mathbf{m o l} / \mathrm{dm}^{3}\right)\end{array}$ & $\begin{array}{c}\text { Total } \\
\text { protein } \\
\left(\mathbf{g} / \mathrm{dm}^{3}\right)\end{array}$ & $\begin{array}{c}\text { Creatinine } \\
\left(\mu \mathbf{m o l}^{3} / \mathrm{dm}^{3}\right)\end{array}$ & $\begin{array}{c}\text { Urea } \\
\left(\mathbf{m m o l}^{3} / \mathrm{dm}^{3}\right)\end{array}$ \\
\hline $100 \mathrm{mg} / \mathrm{kg}$ & $10.28 \pm 0.62$ & $20.66 \pm 0.40^{\mathrm{a}}$ & $77.55 \pm 5.72$ & $7.85 \pm 0.60$ & $72.00 \pm 5.19$ & $59.50 \pm 0.57$ & $8.12 \pm 0.46^{\mathrm{a}}$ \\
\hline $250 \mathrm{mg} / \mathrm{kg}$ & $10.20 \pm 1.39$ & $21.89 \pm 2.37$ & $93.23 \pm 23.08$ & $8.79 \pm 0.93$ & $70.80 \pm 7.46$ & $59.85 \pm 1.03$ & $9.18 \pm 1.07$ \\
\hline Control & $9.40 \pm 0.68$ & $21.38 \pm 0.41$ & $80.85 \pm 11.27$ & $8.33 \pm 1.07$ & $73.80 \pm 5.32$ & $59.75 \pm 0.27$ & $11.10 \pm 1.58$ \\
\hline
\end{tabular}

Values with superscript a are significantly different from control values at $\mathrm{p}<0.05$

Values represent mean $\pm \operatorname{SD}(n=4)$.

The result of the oral acute toxicity indicates that there was no mortality in any groups administered with 2000, 3000, 4000 and 5000 $\mathrm{mg} / \mathrm{kg}$ aqueous leaf extract of Euphorbia lateriflora. However, the treated animals showed signs of depression. According to the toxicity scale of Hodge and Sterner, any compound with an oral $\mathrm{LD}_{50}$ above $5000 \mathrm{mg} / \mathrm{kg}$ should be considered practically non toxic (CCOHOS, 1999).

\section{Discussion}

The mean value of serum ALT activity of control from this study was found to be $9.40 \pm 0.68 \mathrm{U} / \mathrm{dm}^{3}$. From Table 1, it was found that, there was no significant difference $(p>0.05)$ in the serum activity of ALT in groups administered orally with $100 \mathrm{mg} / \mathrm{kg}$ and $250 \mathrm{mg} / \mathrm{kg}$ aqueous leaf extract of Euphorbia lateriflora. This shows that there was no toxic effect after administration of aqueous leaf extract at a dose of $100 \mathrm{mg} / \mathrm{kg}$ and $250 \mathrm{mg} / \mathrm{kg}$.

The mean serum AST activity of control rats from this study was found to be $21.38 \pm 0.41 \mathrm{U} / \mathrm{dm}^{3}$. From Table 1, the AST activity was found to be significantly lower $(\mathrm{p}<0.05)$ than the control in group administered with $100 \mathrm{mg} / \mathrm{kg}$ leaf aqueous extract, but no significant difference $(\mathrm{p}>0.05)$ in group administered with $250 \mathrm{mg} / \mathrm{kg}$. The significantly lower AST activity could be due to the fact that, rats administered with the 
extract for 3 weeks show less appetite than the control group and they were all fed with a feed rich in protein, so, the significantly lower AST activity compared to the control could be as a result of low protein intake. The manifestation of inappetance observed in the rats may however be linked to some chemical constituents present in the extract such as tannins ( Hotellier and Delaveau, 1975). Alldredge (1993) attributed reduce feed intake in animals fed tannin containing diet to strong astringent property of tannins and induction of internal malaise in mammals, which may contribute to reduce feed intake. Several groups of secondary metabolites such as tannins, alkaloids, diterpenes, triterpenes and glucosinolates have been reported in genus Euphorbia lateriflora (Seigler, 1994).

The mean value of serum ALP activity of control rats from this study was found to be $80.85 \pm$ $11.27 \mathrm{U} / \mathrm{dm}^{3}$. From Table 1, it has been found that, there was no significantly difference $(p>0.05)$ in the activity of ALP compared to the control in groups administered orally with $100 \mathrm{mg} / \mathrm{kg}$ and $250 \mathrm{mg} / \mathrm{kg}$ leaf extract of Euphorbia lateriflora. Liver ALP is a non-plasma specific enzyme that is secreted form the sinusoidal surface of the liver cell and thus is present in the serum at low levels in the absence of liver damage (Prince and Stevens, 1989).

The mean total bilirubin of the control rats was found to be $8.33 \pm 1.07 \mu \mathrm{mol} / \mathrm{dm}^{3}$. From Table 1, it was found that, there was no significant difference $(\mathrm{p}>0.05)$ in total bilirubin levels in groups administered with $100 \mathrm{mg} / \mathrm{kg}$ and $250 \mathrm{mg} / \mathrm{kg}$ leaf extract of Euphorbia lateriflora.

The mean serum total protein in control rats was found to be $73.80 \pm 5.32 \mathrm{~g} / \mathrm{dm}^{3}$.From Table 1, it was observed that, there was no significant difference $(\mathrm{P}>0.05)$ in total protein level than the control in both groups administered with $100 \mathrm{mg} / \mathrm{kg}$ and $250 \mathrm{mg} / \mathrm{kg}$ aqueous leaf extract of Euphorbia lateriflora. In addition, it was also observed that the total protein level were found to be lower in groups administered with $100 \mathrm{mg} / \mathrm{kg}$ and $250 \mathrm{mg} / \mathrm{kg}$ leaf extract of Euphorbia lateriflora compared to the control. The lower level of protein seen could be due to the fact that, rats administered with the extract for 3 weeks showed less appetite then the control group and they were all fed with a feed rich in protein. The less appetite seen in the rats could be due to some chemical constituent present in the extract like tannins (Hotellier and Delaveu, 1975). Alldredge (1993) also attributed reduce feed intake in animals fed tannin containing diet to strong astringent property of tannins and induction of internal malaise in mammals, which may contribute to reduce feed intake.

The mean serum creatinine of control rats was found to be $59.75 \pm .0 .27 \mu \mathrm{mol} / \mathrm{dm}^{3}$.From Table1, there was no significant difference $(\mathrm{p}>0.05)$ in the levels of creatinine compared to the control in groups administered with $100 \mathrm{mg} / \mathrm{kg}$ and $250 \mathrm{mg} / \mathrm{kg}$ leaf extract of Euphorbia lateriflora. This shows that, there was no possible kidney malfunction. Creatinine is removed from the plasma by glomerular filtration and is then excreted in the urine without being reabsorbed by the tubules to any significant extent. In addition when plasma level increase above the normal the kidney can also excrete creatinine through the tubules. Consequently, serum or blood creatinine levels in renal disease generally do not increase until renal function is substantially impaired (Faulkner and King, 1982). High serum creatinine may also be indicative of renal failure (Hodgson et al., 1988). Normal renal functions depend on a normal filtration rate. A high glomerular filtration rate leads to excretion of creatinine. In addition, the plasma creatinine concentration may not exceed the upper limits of the reference range until the glomerular filtration rate, and therefore the creatinine clearance, has been reduced by approximately 60 percent (Mayne, 1994).

The mean serum urea of control rats was found to be $10.10 \pm 1.58 \mathrm{mmol} / \mathrm{dm}^{3}$ which appeared to be higher than the reported normal range of $1.7-9.1 \mathrm{mmol} / \mathrm{dm}^{3}$ (Mackay and Mackay, 1927). This shows that the mean serum urea of control obtained in this study differ from the previous studies. The difference may be due to an increased metabolism of proteins or amino acids (Woodraw, 1987). From Table 1, it was observed that serum urea level was significantly lower than the control in group administered with $100 \mathrm{mg} / \mathrm{kg}$. This signifies that there was no possible kidney malfunction.

The significant decrease seen is contrary to the fact that urea concentration is raised in renal disease (Woodraw, 1987). The decrease could be due to the fact that urea concentration is influenced by diet (Annino and Giese, 1976). This could be linked to the fact that, rats in groups administered with the leaf aqueous extract had less appetite than the control and they were all fed with a diet rich in protein, so, the level of urea would be lower in group administered with $100 \mathrm{mg} / \mathrm{kg}$ of leaf extract compared to control. It has been reported that less appetite observed in the rats may however be linked to some chemical constituents present in the extract such as tannins (Hotellier and Delaveau, 1975). Alldredge (1993) also attributed reduce feed intake in animals fed tannin containing diets to strong astringent property of tannins and induction of internal malaise in mammals which may contribute to reduce feed intake. It has been reported that Euphorbia lateriflora contain tannins (Seigler, 1994). From Table 1, it was found that, there was no significant difference ( $p>0.05)$ in creatinine levels in groups administered with $100 \mathrm{mg} / \mathrm{kg}$ and $250 \mathrm{mg} / \mathrm{kg}$ aqueous leaf extract compared to the control. There was a significantly lower urea level in group administered with $250 \mathrm{mg} / \mathrm{kg}$ leaf extract. It has been reported that change in blood urea are normally parallel by changes in blood creatinine (Hodgson et al, 1988). The decrease in urea level could be due to the fact that urea concentration is influenced by diet (Annino and Giese, 1976). 


\section{Conclusion}

The results have shown that the aqueous leaf extract of Euphorbia lateriflora, whengiven orally at a dose of $100 \mathrm{mg} / \mathrm{kg}$ and $250 \mathrm{mg} / \mathrm{kg}$ posses no possible liver damage and kidney malfunction.

\section{References}

[1]. Adjanohoun, E.A., Ake, A., Elewuda, J.A., Dramani, K., Fadoju, S.A., Ebili, Z.O., Johson, C.L.A., Keita, A., Morakinyo, O. Ojeroola, J.A.O., Othunji, A.O., and Safowora E.A. (1991): Traditional Medicine and PremeaCopoena. Contribution of Ethno Botanical and Floristic Studies in Western Nigeria. OAU/Scientific Technical and Research Commission Publication. P. 139.

[2]. Agunu, A., Ibrahim, N.D.G., Oniyiloyi, G.A. and Abdulrahman, E.M., (2003): Toxicity of Stem - bark Extract of SteganotaeniaAraliacea in Rats. Nig. J. Natt. Prod. Med. 7:65 - 67

[3]. Alldredge, J. (1993): The effect of Condensed Tannins on broWsers and Grazers: Quantitative and Qualitative Defense. Colorado: Colorado State University, Fort Collins. P7.

[4]. Annino, J.S. and Giese, R.W. (1976): Clinical Chemistry: Principle and Procedures. $4^{\text {th }}$ edition. Boston: Little Brown and Co. Pp. 51 -84 .

[5]. Arthur,C.G. and John, E.H. (2000): Textbook of Medical Physiology. $10^{\text {th }}$ edition. Philadelphia: W.B. Sounders. Pp. $279-281$

[6]. Bartels, H. and Bohmer, E. (1971): EineMikromethodeZurKreatininbestimmung. ClinchimActa. 32: 81 - 85.

[7]. CCOHOS (1999): What makes Chemicals Poisonous? www.ccohos.ca/oshanswer/chemcials/id50.html.

[8]. Egwin, E.C., Badru, A.A. and Ajiboye, K.O. (2002): Testing pawpaw leaves and African Mahogany Bark for Antimalarial Activities. NSEBT J. 2(1): $37-39$.

[9]. Eisner, T. (1990): Chemical Prospecting. A Call for Action. In: F.H., Borman, S.R. Kellert (eds). Ecology, Economic and Ethics. The Broken Circles Yale University Press.

[10]. Farnsworth, N.R. (1989): Screening Plants for New Medicines. In: E.O., Wilson (eds). Biodiversity, Part II. Washington: National Academy Press. Pp. 83 - 97.

[11]. Faulkner, W.R. and King, J.W. (1982): Renal Function. In: W.T. Norbert (ed). Fundamentals of Clinical Chemistry. USA: WB Sounder Company. Pp. 975 - 978, $994-995$.

[12]. Hambali, M.J. (1990): African Traditional Medicine. A Case Study of Hausa Medicinal Plants and Therapy. Zaria: Gaskiya Cooperation Ltd. P. 78.

[13]. Hodgson, E., Mailman, R.B., and Chambers, J.E., (1988): Macmillan Dictionary of Toxicology. London: The Macmillan Press. Pp. $31,62,89,100,164,186-218$ and 322 .

[14]. Hotellier, F.P and Delaveau, P. (1975): Nauclefine andNaucletine Constituents ofNaucleaLatifolia. Phytochem. 14: 1407 - 1411

[15]. Jendrassik, L. and Grof, P. (1938): Colometric Method for Serum Bilirubin Determination. Biochem Z: 297: 81

[16]. Mackay, E. M., and Mackay, L.L. (1927): Normal Values of Serum Urea. J. Clin. Invest. 4: 295.

[17]. Mayne, P. (1994): Liver. In: Clinical Chemistry on Diagnosis and Treatment. $6^{\text {th }}$ edition. London: Philop D. Mayne. P. 281.

[18]. Mayne, P. (1994): Kidney. In ClinicalChemistry on Diagnosis and Treatment. $6^{\text {th }}$ edition. London: Philop D. Mayne. Pp. 19-13.

[19]. Obi, R.K., Iroagba, I.I. and Ojiako, O.A., (2006): Vicacidal Potential of Some Edible Nigerian Vegetables. Afric. J. Biotech. 5(19): $1785-1788$.

[20]. Ogunyemi, A.O. (1979): The Origin of the Herbal Cure and its Spread. In: Proc. Of a Conference of African Medicinal Plants (Safowora, A. (ed) University of Ife Press, Ile - Ife. Pp. 20 - 22.

[21]. Prince, N.C. and Stevens, L. (1989): Clinical Aspects of Enzymology. Fundamentals of Enzymology. $2^{\text {nd }}$ edition. Oxford: Oxf. Univ. Press. Pp. $454-459$.

[22]. Rec. GSCC (DGKC). (1972): Colorimetric Method for Serum Alkaline Phosphatase Determination. J. Clin. Chem. Clin.Biochemistry: 10: 182

[23]. Reitman, S. and Frankel, S. (1957): Colorimetric Method for the Determination of Serum Glutamic Oxaloacetate and Glutamic Pyruvic Transaminases. Amer. J. Clin. Path. 28: 56.

[24]. Seigler, D.S. (1994): Phytochemistry and Systematic of the Euphorbiaceace. Annals of the MissouriVot. Gard. 81: 381 - 401.

[25]. Sule, M.S., Bichi, L.A., Atiku, M.K., (2002): Antimicrobial and Preliminary Phytochemicals Screening of G. Senegalensis,Euphorbia lateriflora and Mitrcapusscaber. WestAfrican J. Pharmncol. Drug Res. 18, 12 - 13.

[26]. Weichselbaum, T.E. (1946): Determination of Total Protein of Serum and Plasma. Amer. J. Clin Path., 16:40.

[27]. Weatherburn, M.W., (1967): Colorimetric Methods for Serum Urea Determination. Anal. Chem: 39: 971.

[28]. Woodraw, D.A. (1987): Introduction to Clinical Chemistry. London: Butterworth and Co. Ltd. Pp. 47 - 59. 